\title{
Leary Site Revisited: Oneota and Central Plains Tradition Occupation along the Lower Missouri
}

\author{
Lauren W. Ritterbush
}

\begin{abstract}
Archaeologists of the central Plains and prairie peninsula have known of the Leary site (25RH1) in extreme southeastern Nebraska for more than 85 years. Early archaeological visitors to the site concluded that its remains were distinctly different than those from more common Central Plains tradition sites in the region. Instead, the Leary ceramics compare favorably with those from Oneota sites typically found to the east. The apparent anomalous position of this Oneota settlement in the central Plains indicates trans-Missouri movement of Oneota peoples into the eastern Plains. Leary is significant for the clues it holds regarding overall Oneota expansion during the Late Prehistoric period, as well as possible cultural interaction with Plains populations. The latter is especially relevant due to the fact that archaeological remains of the Central Plains tradition are also present at the Leary site. Analysis of curated assemblages collected during 1935 and 1965 suggests multiple Central Plains tradition occupations bracketing or overlapping those associated with the Oneota tradition. This and other finds at the Leary site raise interesting research questions to be addressed through future archaeological studies.
\end{abstract}

\section{Keywords: Oneota, Central Plains tradition, Leary site}

The Leary site (25RH1), located on a low terrace of the Big Nemaha River above its confluence with the Missouri (Figures $1 \& 2$ ), has held the interest of Plains and Midwestern archaeologists since the early twentieth century. Numerous researchers have visited and conducted excavations in various portions of this large site. A summary report of one of the most extensive excavations conducted in 1935 remains the most available source describing Leary (Hill and Wedel 1936). Other investigations have yet to be summarized and are only briefly mentioned in the professional literature. Despite the long and widespread interest in this site, few questions have been answered about its prehistoric occupants and their role in regional cultural dynamics. This paper prepares the way for those studies through a review of previous investigations, interpretation of the general culture history, and discussion of modern research questions relevant to the prehistoric occupation of the Leary site.

\section{HISTORY OF INVESTIGATIONS}

As noted by Hill and Wedel (1936:8-10), William Clark first mentioned evidence of Native American use of the Leary site on July 12, 1804. On that day the Lewis and Clark expedition stopped near the mouth of the Big Nemaha River to rest on their Missouri River journey and record observations about the region. Clark took a short excursion up the Nemaha to present-day Roys Creek. Here on the bottomland prairie alongside the creek and Nemaha River, Clark noted small mounds that were likely midden or house deposits (Moulton 1986:368-373; Hill and Wedel 1936:8-10). Higher on the valley bluffs he noted burial mounds that were associated, at least in part, with the prehistoric occupation of the valley.

More than 100 years later, Frederick H. Sterns of the Peabody Museum of Harvard University visited the region and noted the location of what he called the Nemaha Camp Site (Sterns ca. 1915). $\mathrm{He}$ described the site as consisting of a number of

Lauren W. Ritterbush, Department of Sociology, Anthropology and Social Work, Kansas State University, Manhattan, KS 66506-4003. 


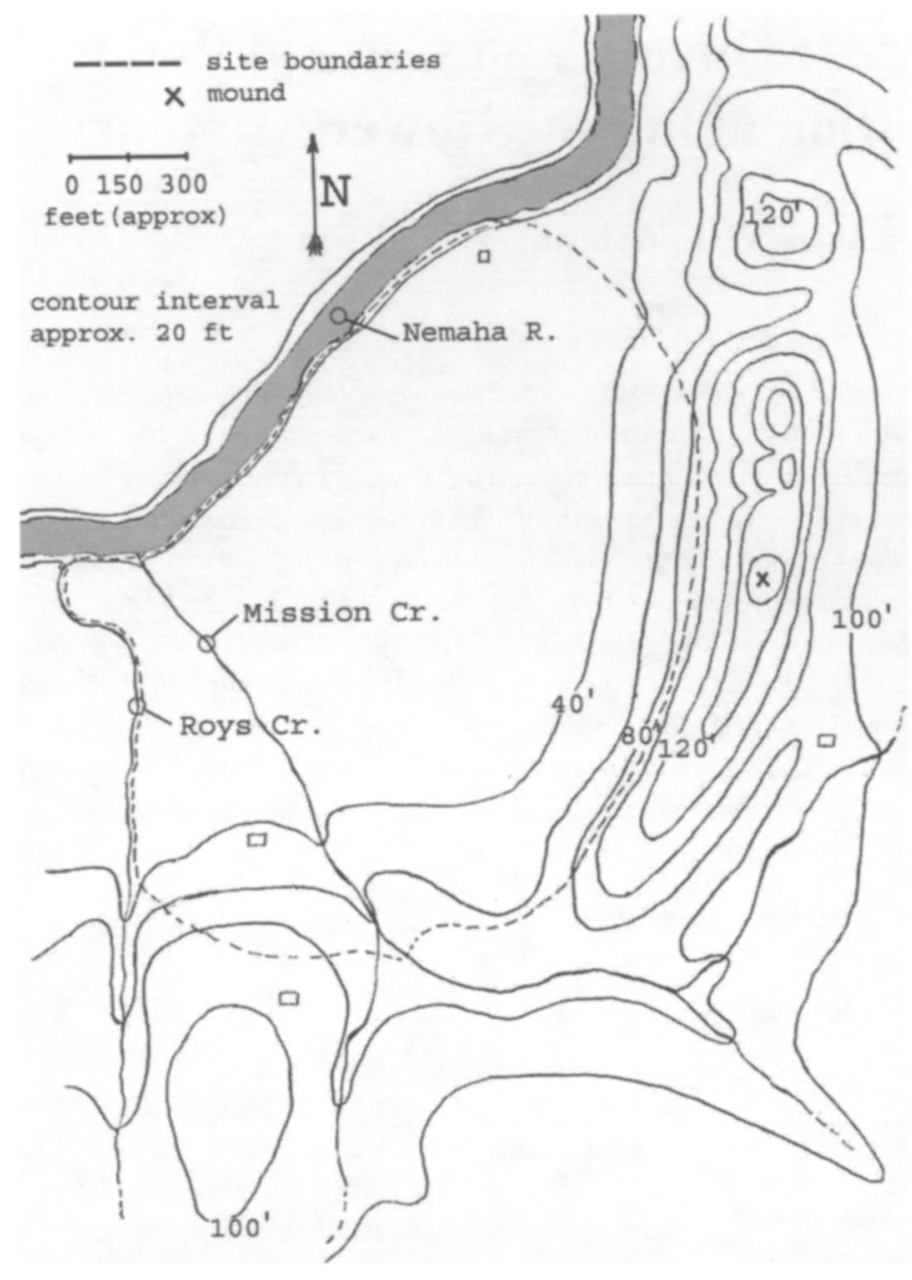

Figure 1. Generalized map of the Leary site modified from a sketch included in F. H. Sterns notes (Peabody Museum of Archacology and Ethnology, Harvard University, Collection Department, Accession File 15-6.)

lodges on the slope of the Nemaha River valley below the adjacent Missouri River bluffs (Figure 1). By this time plowing had already disturbed house outlines and prehistoric burials, several of which he excavated (Anonymous 2000; R. Eric Hollinger, personal communication 2000). Local landowners and artifact collectors undoubtedly directed Sterns to the site as they were well aware of its location, impressive size, and associated cultural material. In 1918 one of the prominent artifact collectors in the region, Mark E. Zimmerman, noted the uniqueness of the Leary and Fanning sites (although Fowke [1922:153] did not agree with his interpretation about Leary) (Zimmerman 1918:474). Both of these sites contained shell-tem- pered pottery instead of the more common stone- or sherdtempered ceramics found at other sites in the region. E. E. Blackman, who conducted excavations at Leary over a threeweek period in 1926, also noted this attribute (Hill and Wedel 1936:12; Blackman ca. 1926). As stated by Blackman (ca. 1926), "the pottery [from the Leary site] is the avenue through which the people who built this site will eventually be definitely determined."

W. Duncan Strong made this determination after inspection of artifact collections from the site. In his summary of the prehistoric cultural sequence of Nebraska, Strong (1935:288289) discussed the potential of finding Oneota and Mill Creek archaeological remains in eastern Nebraska. Here he noted "the possibility that the true Oneota culture is represented in the shell-tempered and roughly incised pottery of the Rulo [Leary] site in extreme southeastern Nebraska and perhaps elsewhere in the eastern part of that State where shell-tempered pottery has been noted" (Strong 1935:288).

An evaluation of Strong's interpretation of Leary as a western Oneota site was undertaken in 1935. During a three-week period in the summer of that year, A. T. Hill of the Nebraska State Historical Society (NSHS) oversaw excavations on the property of Ed F. Leary and James P. Kelly (Figure 3). Hill, assisted by George F. Lamb and a crew including Marvin Kivett, Walter Rasmussen, John Adams, Fulton Gantt, and occasionally E.C. Harte, located and excavated most of 153 pits, one house, and seven burials, in addition to 15 scattered test excavations (Hill and Wedel 1936). The publication by Hill and Wedel (1936) of their analysis of the recovered remains is still the most widely avail- 


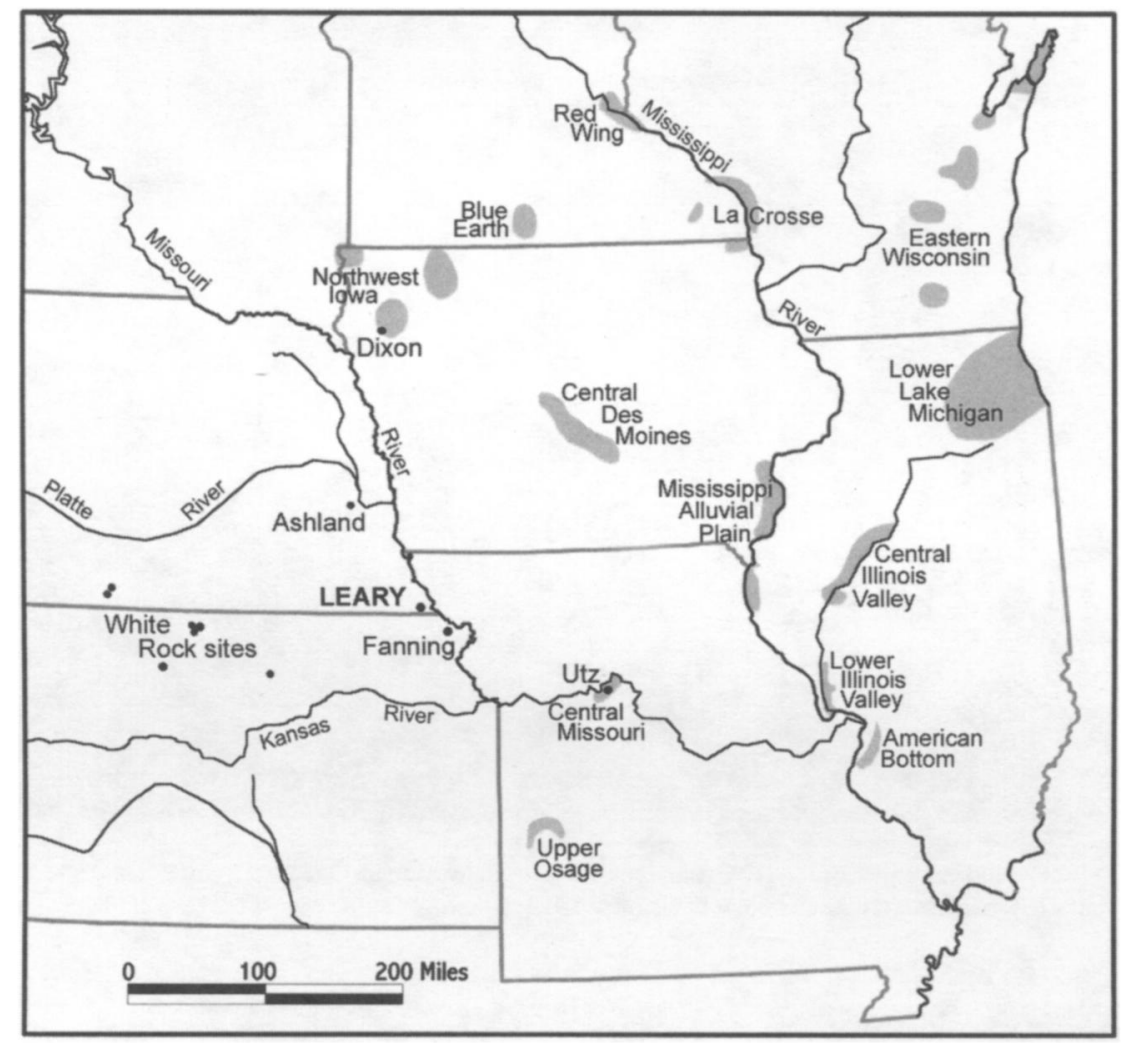

Figure 2. Regional map illustrating the location of Leary and other Oneota sites mentioned in the text. Shaded areas denote Oncota site localities in the prairie peninsula.

able source about this site. As noted by Charles $\mathrm{R}$. Keyes in his 1938 review of this publication, Hill and Wedel clearly show that the majority of the cultural remains from the Leary site is comparable to materials from Oneota sites more commonly found in the prairie peninsula to the east (Keyes 1938).

Thirty years after A.T. Hill led an excavation crew at Leary that included a young Marvin Kivett, Kivett sent a crew back to conduct further excavations. John Garrett and subsequently Wendell Frantz directed a Nebraska State Historical Society crew for roughly ten weeks during the summer of 1965 (Figure 4). During that time they excavated 30 pits, three burials, another house, and various other features (e.g., house hearth and postmolds, artifact concentration, and areas of burned earth) (Frantz 1966; Garrett and Frantz 1965). Their excavations were conducted in a portion of the site that had not been tested in 1935 and uncovered both Oneota and Central Plains tradition (CPT) artifacts. Unfortunately, these materials were not systematically analyzed and remain unpublished (Corbyn 1975).

Various institutions and individuals have undertaken other investigations of the Leary site. The University of Nebraska Archaeological Survey visited the site in 1939 and excavated two or three pits (notes and catalog on file with the University of Nebraska State Museum). J. Mett Shippee, Jack T. Hughes, and Wesley L. Bliss made a surface collection at leary in 1947 as part of the River Basin Sureys (River Basin Survey, Site Files, National Anthropological Archives, Washington, DC). William M. Bass (1961) visited Leary in 1960 to salvage materials from eight burials or storage pits that had been uncovered during road maintenance. Material remains from these features compared favorably with the Oneota artifacts found earlier by Hill's crew. At this time Bass also excavated por- 


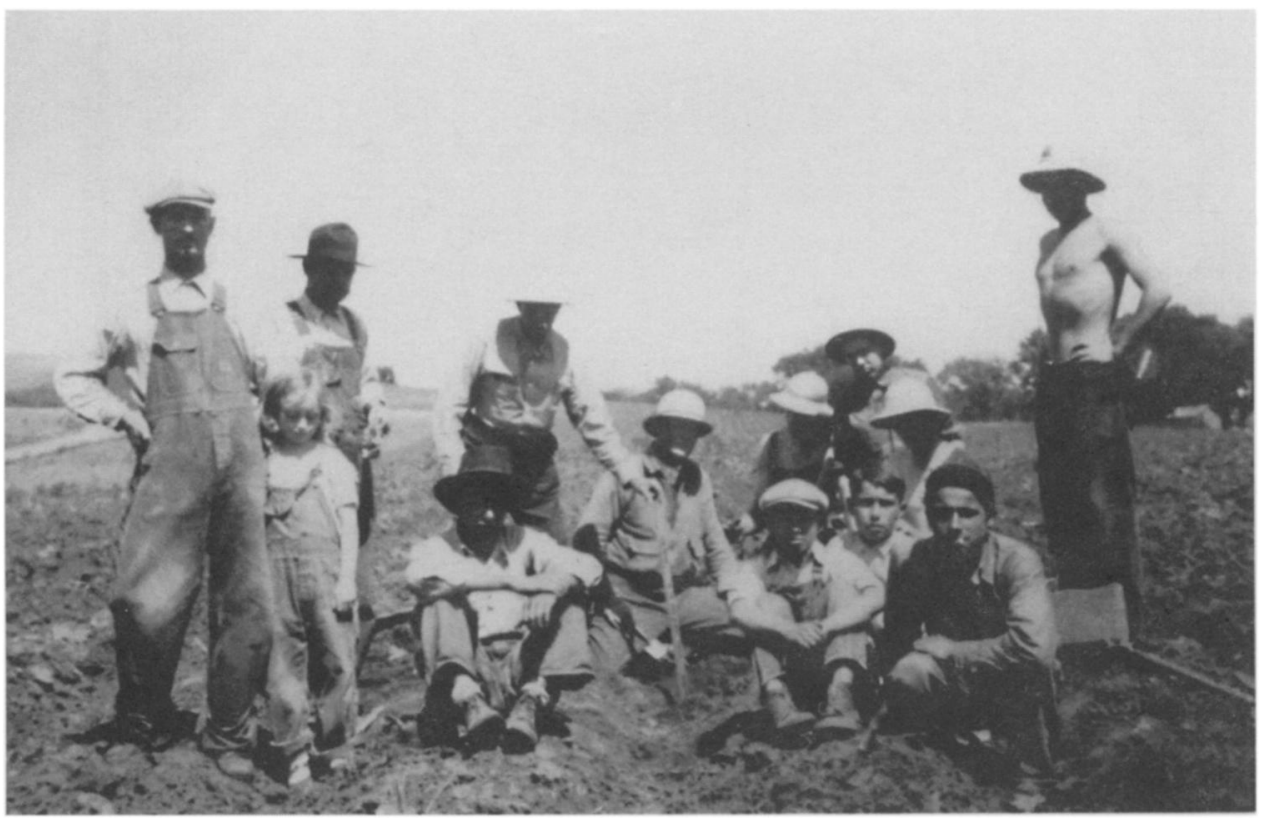

Figure 3. The 1935 excavation crew and local Native American visitors uncovering an Oneota pot at the Leary site. Photo courtesy of the Nebraska State Historical Society, Archeology Division.

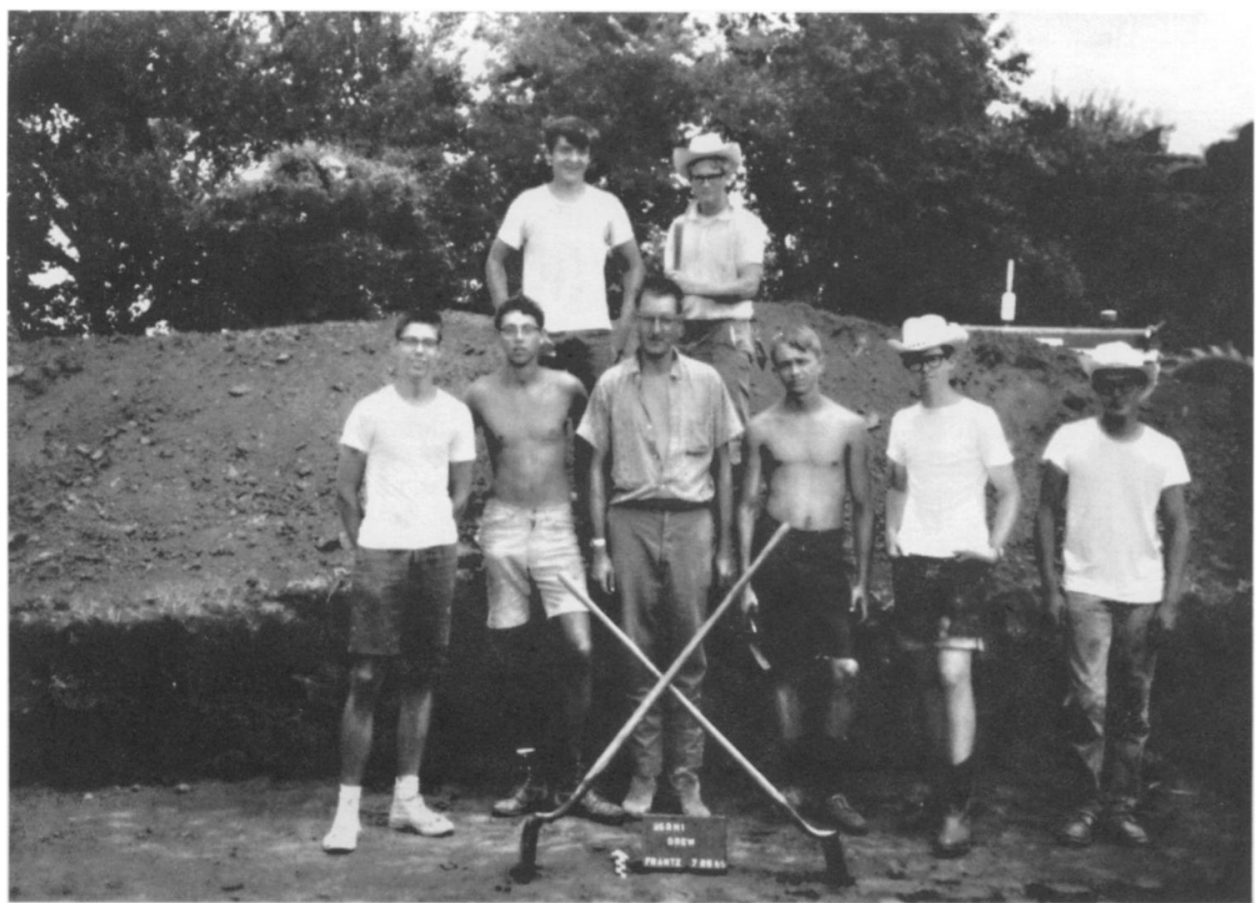

Figure 4. The 1965 Leary site excavation crew. Front (l-r): Harold Sammons (cook), Travis Gray, Wendell Frantz, Joel Babbs, Mick Lowe, Tim Valder. Back (1-r): Nick Frankforter and John Ehrenhard. Photo courtesy of the Nebraska State Historical Society, Archeology Division. 
tion of a burial mound atop a nearby bluff. This may have been the same mound that was rumored to have been dug into in 1914 by William Barada (Corbyn 1975). In 1965 J. Mett Shippee excavated at least one pit at Leary that contained Oneota sherds. Charcoal from this feature was the first material from the site to be radiocarbon dated (Bender et al. 1967; Henning 1970:145, 153). Additional salvage excavations were carried out under the direction of Alfred E. Johnson during the summer of 1968. Johnson led a group of field school students from the University of Kansas, Kansas State University, and Wichita State University in the excavation of five pits and three burials in the northwestern portion of the site. Several of these features were found eroding out of a recent bulldozer cut along the terrace of the Nemaha River (records on file at the University of Kansas Museum of Anthropology; Garst 2002). They too were associated with Oneota ceramics. The Nebraska State Historical Society has been called to salvage accidental discoveries, such as in 1979, and to monitor nearby constructions on several occasions since the 1960s. In 1993 the Archaeological Research Laboratory of Wichita State University conducted limited test excavations in areas adjacent to and within the Leary site boundaries in advance of planned bridge and culvert replacements (Johnson 1993).

The Archeology Division of the Nebraska State Historical Society curates the artifacts and documents from the 1926, 1935, 1965, and 1979 excavations (Table 1), as well as several small surface and donated collections from the site. Human remains uncovered during 1935 and 1965 have been repatriated (McManamon 1997). Samples of ceramics from the 1935 excavations were transferred to the Smithsonian Institution and the University of Michigan Museum of Anthropology (Table 1). The Sterns Collection is housed at the Peabody Museum of Archaeology and Ethnology of Harvard University (Anonymous 2000; R. Eric Hollinger, personal communication 2000). Artifacts collected by or given to Mark Zimmerman are now curated by the Kansas State Historical Society and the Smithsonian Institution. The Office of the State Archaeologist at the University of Iowa curates the Keyes Collection, which includes ceramics from the surface of the Leary site. The University of Nebraska State Museum cares for those artifacts that

Table 1. Chronology of major excavations at the Leary site. Repositories of excavated materials include the Peabody Museum of Archaeology and Ethnology at Harvard University, Nebraska State Historical Society (NSHS), University of Michigan Museum of Anthropology (UM), Smithsonian Institution (SI), University of Nebraska State Museum (UNL), University of Kansas Museum of Anthropology (KUMA), and Wichita State University (WSU).

\begin{tabular}{|c|c|c|c|c|}
\hline Year & Project Director & Crew Supervisor & Repository & Reference \\
\hline 1915 & F. H. Sterns & & Peabody & Sterns ca. 1915; Anonymous 2000 \\
\hline 1926 & E. E. Blackman & & NSHS & Blackman ca. 1926 \\
\hline 1935 & A. T. Hill & G. Lamb & NSHS, UM, SI & Hill and Wedel 1936; McManamon 1997 \\
\hline 1939 & & Gilmore \& Ward & UNL & $\begin{array}{l}\text { (catalog on file with the University of } \\
\text { Nebraska State Museum) }\end{array}$ \\
\hline 1960 & W. M. Bass & W. M. Bass & & Bass 1960 \\
\hline 1965 & M. Kivett & J. Garrett \& W. Frantz & NSHS & $\begin{array}{l}\text { Garrett and Frantz 1965; Frantz 1966; } \\
\text { McManamon } 1997\end{array}$ \\
\hline 1968 & A. E. Johnson & A. E. Johnson & KUMA & Garst 2002 \\
\hline 1979 & & C. Jones & NSHS & (specimen inventory at the NSHS) \\
\hline 1993 & D. Hughes & C. Johnson & WSU & Johnson 1993 \\
\hline
\end{tabular}


were recovered in 1939 (notes and catalog on file at the University of Nebraska State Museum). The human remains excavated by Bass in 1960 have been repatriated (Beth Wilkins, University of Nebraska State Museum, personal communication 2002). The University of Kansas Museum of Anthropology curates the non-skeletal remains salvaged in 1968, while the Kansas State University Archaeology Lab holds a small surface collection made that same summer. The University of Tennessee includes skeletal remains from the Leary site in their NAGPRA inventory. These may be from the burials excavated by the University of Kansas in 1968. Additional materials reside in numerous personal collections, including that donated by R.B. Aker to the University of Kansas Museum of Anthropology.

The Leary site was nominated to the National Register of Historic Places in 1975 (Corbyn 1975). A plaque mounted on a brick marker at the site identifies it as a National Historic Landmark. The entire site lies within the reservation boundaries of the Iowa Tribe of Kansas and Nebraska.

\section{SITE INTERPRETATIONS}

The most noteworthy interpretation to date of the Leary site has been its identification with the Oneota tradition (Hill and Wedel 1936; Keyes 1938; Strong 1935). This affiliation is especially interesting given the western location of the Leary site relative to most other Oneota sites (Figure 2). Frantz (1966) and others (Anonymous 2000; Corbyn 1975; O'Brien and Wood 1998:354; Bozell and Ludwickson 1999) also noted the presence of Central Plains tradition remains at the site.

The majority of materials uncovered during the extensive excavations of 1935 can be identified with the Oneota tradition. This includes features and artifacts from all areas tested in 1935, namely from the southeastern and east-central portions of the site. The strongest suggestion for a Central Plains tradition occupation is a house feature found near the surface in the latter area (Figure 5). This structure was marked by a number of

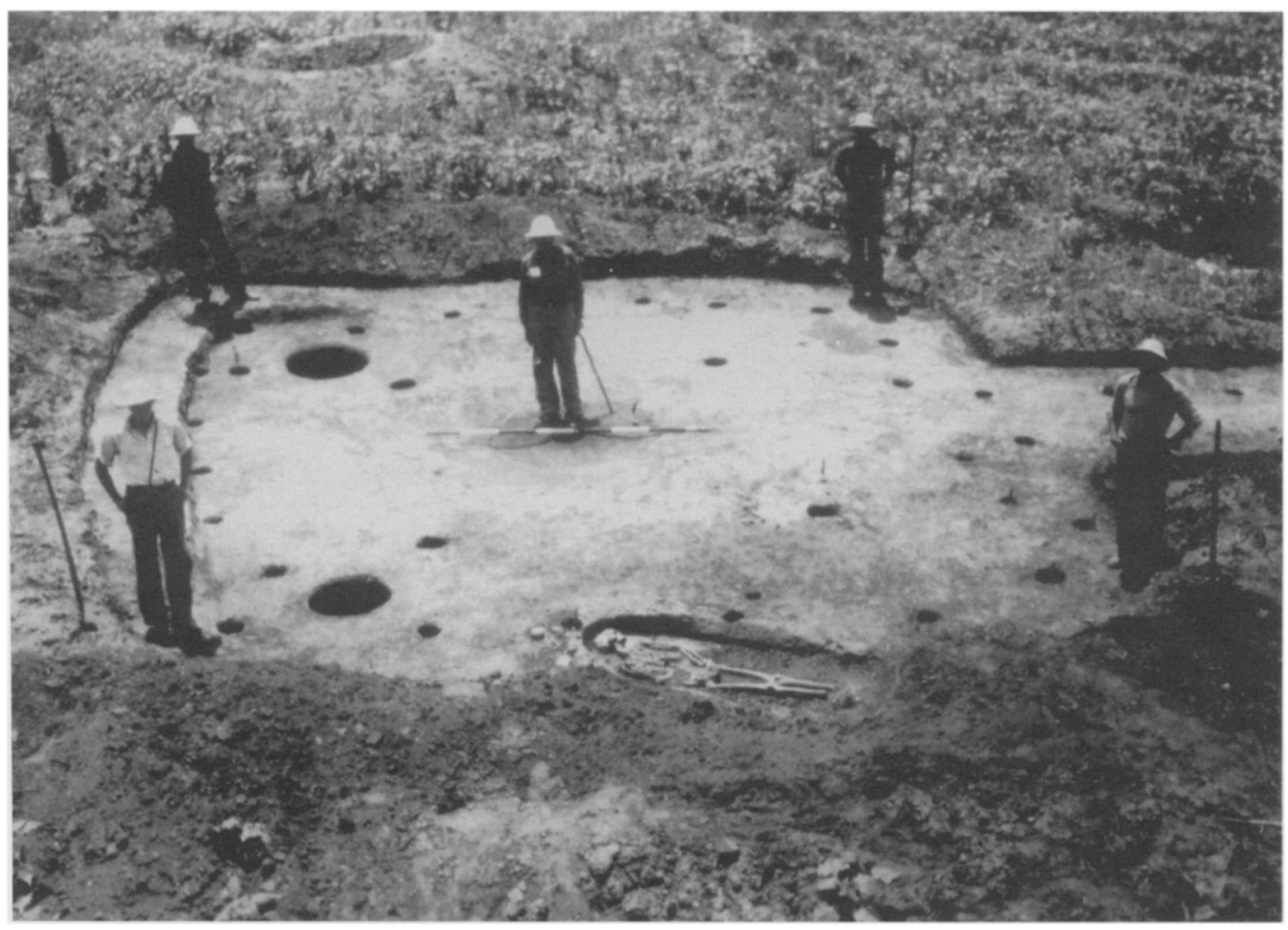

Figure 5. House floor excavated in 1935. Photo courtesy of the Nebraska State Historical Society, Archeology Division. 
wall posts outlining a sub-rectangular floor measuring $20 \times 21$ feet, a central firepit, and four large roof support posts forming a rough square between the walls and fireplace (Hill and Wedel 1936:15). Two parallel rows of postmolds marked a 15-foot long, four-foot wide entrance passage extending west-southwest (Hill and Wedel 1936:15-19). Two cache pits (C. $1 \& 2$ ) were associated with the house floor. This structure compares favorably with Central Plains tradition houses common in the region (Steinacher and Carlson 1998). Similar forms are not generally found at Oneota sites (Hollinger 1993). This and a comparable find associated with the late prehistoric Oneota component at the Ashland site (25CC1) in east-central Nebraska raise questions whether some western Oneota migrants interacted with indigenous Central Plains tradition peoples or adopted the common house form of local populations (Hill and Cooper 1937; Pepperl 2000).

Formal similarities exist between the house excavated at Leary in 1935 and Central Plains tradition houses. Nonetheless, Hill and Wedel (1936) were unwilling to assign a Central Plains tradition affiliation to it. Instead, they suggested Oneota occupation of the structure based on several sets of data. First, the majority of the artifacts uncovered during excavation of the house floor and contemporaneous pits compares favorably with Oneota materials (Hill and Wedel 1936:18). Indeed, 79.5\% of the 39 potsherds from the floor and the only pit (C. 1) containing artifacts is clearly shell-tempered. Eighteen of these sherds exhibit lip or shoulder decorations with design elements common on Oneota ceramics. However, four rim and four body sherds have attributes that are frequently associated with certain Central Plains tradition ceramics. These include grit temper or shell that has leached out of the paste, smoothed-over cord markings, and low rolled rims. One rim is from a small constricted-mouth bowl decorated with a single line encircling the mouth just below the lip. This and two other rims are comparable to sherds recovered from the Steed-Kisker, Friend and Foe, and Scott sites located to the south in neighboring Missouri and Kansas (Calabrese 1969:243 Plate 2c; Wedel 1943:Plate 24f-g; Brad Logan, personal communication 2001). On the basis of these comparisons and the above-mentioned attributes, certain ceram- ics from the 1935 house are identified as Platte Valley ware (Calabrese 1969:197-200). An additional series of crossmended sherds may lend further support to this interpretation; however, it is impossible to determine this at this time. These sherds were used to form a reconstructed vessel, which, unfortunately, has not been found at the NSHS (Rene Botts, archaeological curator, NSHS, personal communication, January 11, 2002). An old photograph of this pot indicates that it had a globular shape more similar to that of Central Plains tradition than most Oneota vessels. Other attributes visible in the photograph include a relatively low flared rim, a smooth body surface treatment, and no readily apparent lip-top or shoulder decoration. These anomalous sherds and the form of the 1935 structure suggest that this house and the upper cultural stratum of the site may be affiliated with the Steed-Kisker phase. The mix of Steed-Kisker and Oneota ceramics may be due to direct interaction between peoples of these two traditions or disturbance of underlying Oneota deposits by the builders of the house.

The 1935 excavation uncovered additional cache pits and several burials in the area of this house (Figure 6). All but the two mentioned above (C. $1 \& 2$ ) reportedly lay below the living floor, indicating that they were filled prior to construction of the house (Hill and Wedel 1936). This is confirmed by post molds intrusive into earlier filled features, namely caches $96,99,99 \mathrm{~A}, 102$, and 105 , as well as burial 7. Only caches 96 and 99 held diagnostic materials. These included smooth, shelltempered ceramics with typical Oneota lip and shoulder decoration. Like most of the other ceramics recovered in 1935 from pits in the southeastern portion of the site and from general surface survey, these are assigned to the Oneota tradition.

A second house was uncovered at the Leary site in 1965. This feature was located in the northcentral portion of the site near the Nemaha River and a substantial distance from the structure uncovered in 1935. This house appears to have been constructed over a roughly square pit up to one foot deep with rounded corners and measuring approximately 39 by 37 feet (Figure 7). Nine scattered post molds and pieces of charred wood were found on portions of the house floor. A hearth $(\mathrm{F}$ 19), partially destroyed by an intrusive pit, marked 


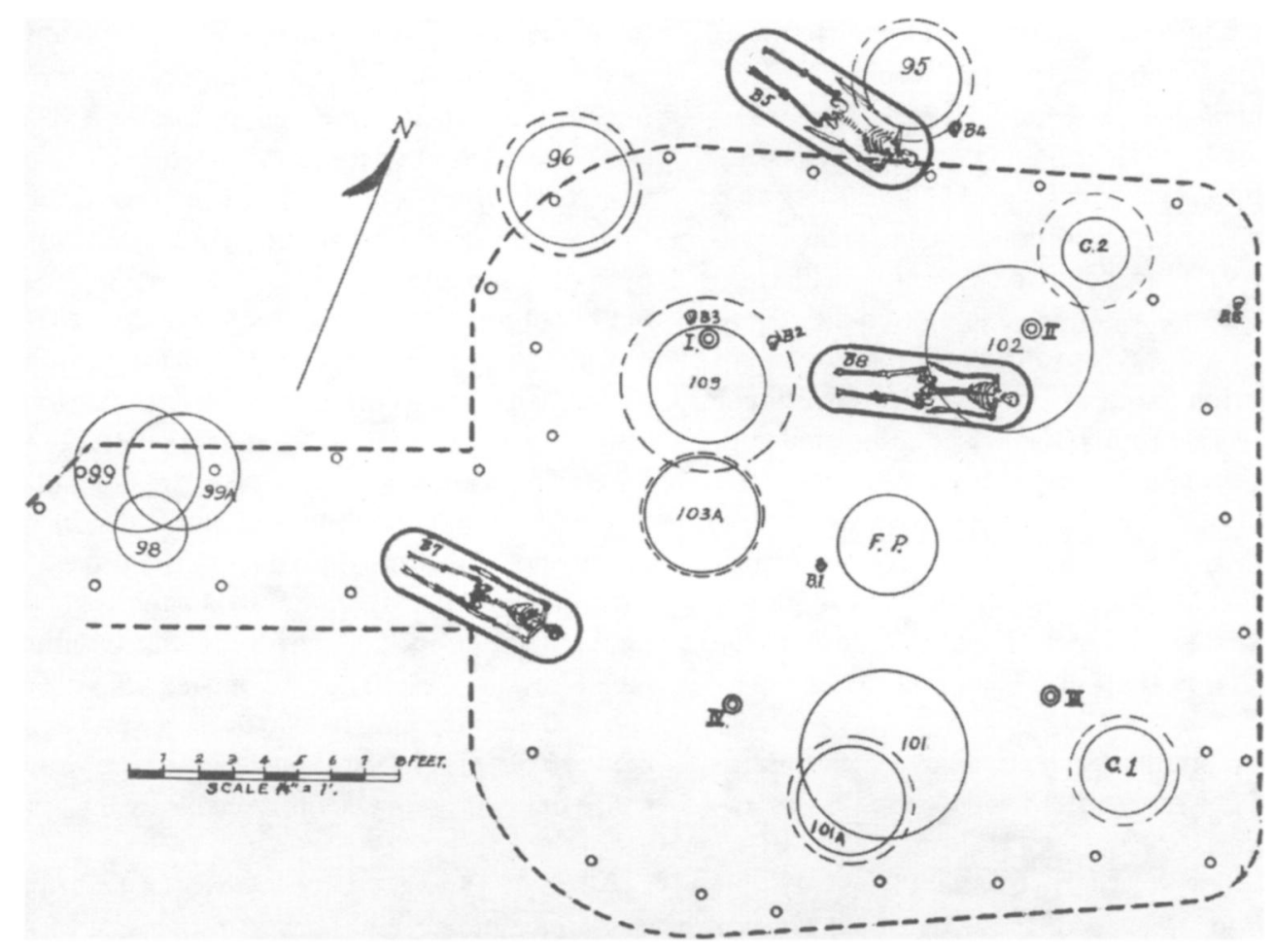

Figure 6. Plan of the house floor and underlying pits and burials uncovered at the Leary site in 1935. The post molds, fireplace, and caches 1 and 2 are associated with the house floor. All other pits and burials lie below the floor. (Hill and Wedel 1936:16 Fig. 2) Reproduced with permission from the Nebraska State Historical Society.

the center of the floor at 3.5 feet below the modern ground surface. Although the plan of this structure does not match Central Plains tradition houses as clearly as the 1935 feature, the general outline, plan, and size of the 1965 house are similar to Central Plains tradition lodges (Steinacher and Carlson 1998). The most comparable Oneota structures are Features 11, 16, and 20 at the Dixon site, located north of Leary in northwestern Iowa (Figure 2) (Fishel 1999:33-45). These structures appear to have a rectangular or oval outline, internal hearth, wall posts, and a semi-subterranean floor. Unfortunately, these remains (and potentially those excavated in 1965 from the Leary site) are incomplete, preventing thorough comparative analysis.

Artifacts recovered during excavation of the 1965 house include both Oneota and Central Plains tradition ceramics. The latter include grit or sandtempered rim and body sherds, most with cord- marked exteriors (Middleton 2001). Rims are direct and straight to flaring with a plain rounded lip or exterior lip pinching. Oneota sherds were also found during excavation of the lodge in the matrix overlying the floor and in most pit features. Unfortunately, these pits were indistinct in the mixed matrix overlying the house and appear to have been overlooked until excavations had reached the rooffall or house floor (Garrett and Frantz 1965:18). As a result, it is impossible at this time to identify which of the pits were intrusive into the house feature. An exception is Feature 23, consisting of the lower portion of a probable bell-shaped cache pit, a second basin-shaped pit, and an oval "pocket cache." The former intruded into the central fireplace (F 19) indicating that it was intrusive from a later occupation. Most of the other pits are also believed to be intrusive. This later (overlying) occupation was by Oneota peoples, as indicated by 


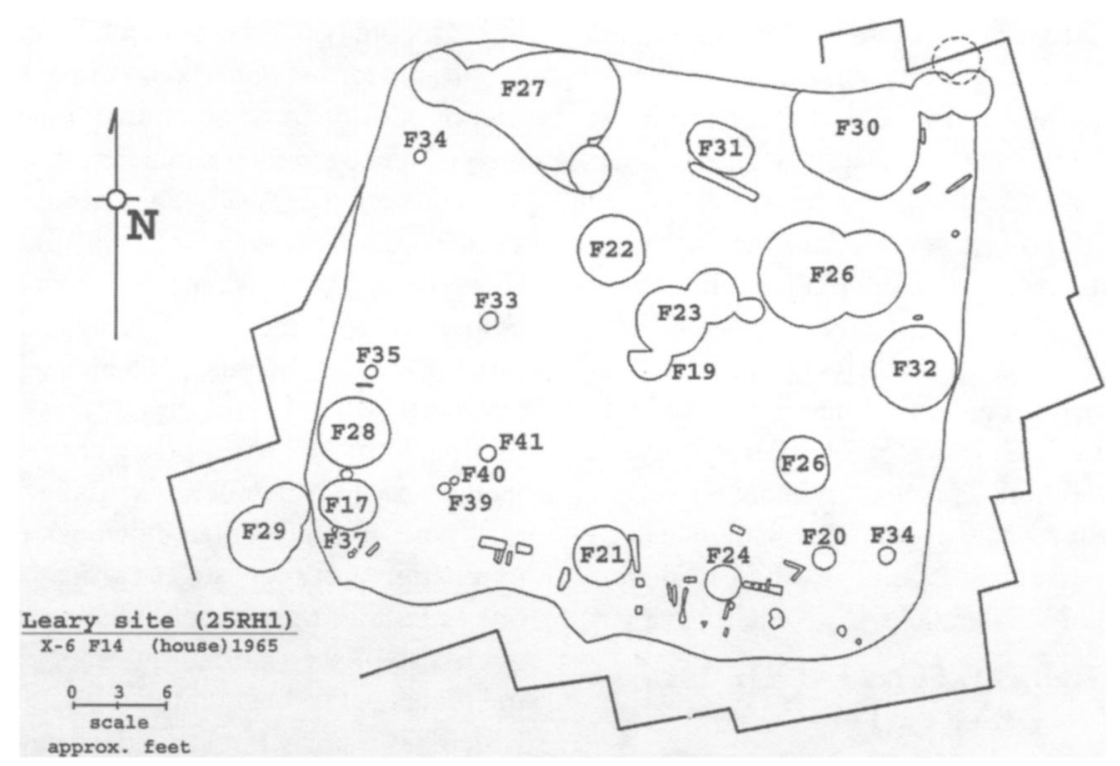

Figure 7. Plan of excavation unit 6, Feature 14 (house) as excavated in 1965. Reproduced from maps curated by the Archacology Division of the Nebraska State Historical Society.

the predominance of ceramics of that tradition. Activities, such as the excavation of cache pits into underlying (CPT) deposits, by these later occupants may explain the mix of Central Plains and Oneota tradition ceramics in this portion of the site. Frantz (1966:163) suggested this in his preliminary comments regarding the 1965 excavation:

The house floor was covered by 2.5 feet of mixed soil representing the Oneota occupation. Twentyone pits were found in the house floor excavation. Two can definitely be attributed to the occupation of the house. Ten pits are evidently intrusive from above.

Analysis of materials excavated in 1965 has resulted in the interpretation of a Nebraska phase component in the lower stratum of the north-central portion of the Leary site (Bozell and Ludwickson 1999; Frantz 1966; Middleton 2001). The majority of the grit- or sand-tempered cordmarked sherds from this portion of the site is identified as McVey ware with plain and tool- or finger-decorated, unthickened rims (Gunnerson 1952). Similar ceramics are common at Nebraska phase sites in eastern Nebraska and the Glenwood locality in neighboring Iowa (Gunnerson 1952, Ives 1955). In this situation, however, the Nebraska phase ceramics are mixed with Oneota ceramics. This may indicate direct interaction between people of these two traditions. An alternative hypothesis is that sequential occupations occurred in the same portion of the site with Oneota activities resulting in the disturbance of earlier Nebraska phase deposits. This is evident from the recognition of a pit intruding into the central fireplace of the 1965 house. Unfortunately it is impossible to discern if this is true of the other features in this portion of the site.

In sum, the early interpretation of Leary as an Oneota site is clearly valid for much of the site. Oneota sherds dominate all of the ceramic subassemblages I have seen from the site. Nonetheless, analyses of the 1935 and 1965 assemblages suggest that other archaeological components are also present. The earliest known occupation of Leary is represented by the house uncovered in 1965 in the north-central portion of the site. It was occupied by Nebraska phase people or a combined Nebraska-Oneota population. Subsequent Oneota settlement included this and other portions of the site, extending widely over the sloping terrace. Those Oneota occupants living near the Nemaha likely disturbed the earlier deposits in that area, 
while others lived in areas not utilized by previous populations. This extensive Oneota component was disturbed in the east-central portion of the site by house-building and living activities of the latest documented prehistoric occupants of Leary. Their remains are associated with the house uncovered by Hill in 1935. Unfortunately, their identity is not obvious due to the small sample of ceramics from this structure, mixture of ceramic types, and evidence of disturbance of underlying deposits. The ceramics associated with this house are tentatively identified with both the Steed-Kisker phase and the Oneota tradition. This may indicate a joint occupation by Steed-Kisker and Oneota peoples or a Steed-Kisker occupation that resulted in disturbance of earlier Oneota debris.

\section{RESEARCH POTENTIAL OF THE LEARY SITE}

The foregoing discussion of the general cultural stratigraphy of Leary reveals that much has yet to be learned from this site. Among the research questions to be addressed is whether more than one Oneota component is represented here (Corbyn 1975). This idea was raised by Dale R. Henning more than 30 years ago when he noted that both early (Correctionville) and late (Allamakee) ceramics are present at Leary (Henning 1961, 1970:145, 152-153; 1998:393-394). Ceramic variation within the Leary site assemblage was shown to exist through a factor analysis of ceramic attributes as conducted by Carol Raish (1979:83-84). More recently, Christine Garst (2002) documented the presence of both early (Developmental horizon) and late (transitional or Classic horizon) Oneota ceramics in the western portion of the site. Her attribute analysis focused on ceramics recovered from features salvaged in 1968 and utilized the model of Oneota development devised by Boszhardt (1998) to identify ceramic horizon markers. The results of these preliminary studies, pending more thorough analysis of the Leary site ceramics, suggest that Oneota peoples occupied this site for some time or at multiple times during the Late Prehistoric period. The presence of a number of overlapping pit features (such as Features 98, 99, and 99A, 101 and $101 \mathrm{~A}$, and 103 and 103A below the 1935 house [Figure 6] and the various pits identified in 1965 as Feature 23 [see above and Figure 7]) lend sup- port to this general conclusion of long-term or multiple Oneota occupations at the Leary site.

Radiocarbon dates could aid in the interpretation of periods of occupation, although it may be impossible to overcome inherent limitations of this dating technique. Seven radiocarbon dates are now available for Leary (Table 2). The first pair of dates (SI-618, SI-617) was obtained from charred wood associated with the house excavated in the lower portion of the site in 1965. Bozell and others (1999:102-105, 121) analyzed these dates as part of a study of Nebraska phase chronology and rejected one. (No detailed discussion of these specific dates was presented; however, potential contamination was suggested as grounds for rejecting one or both of these dates.) The earliest date does not fit established chronologies for either the Central Plains or Oneota traditions, while the later date, which has a fairly large standard deviation, could theoretically fit either a Nebraska phase or Oneota tradition occupation. Bozell and others (1999:102105 ) imply that the latter is too late for a Nebraska phase occupation although the ceramics appear to fit this phase. Recently two additional radiocarbon assays (BGS 2301, BGS 2302) were obtained on curated charcoal samples from the 1965 house excavation (Table 1). The calibrated ranges of the two dates overlap with one another and with the broader range of the second, more reasonable date obtained earlier for this feature. One of these newly obtained dates (BGS 2302) also very closely matches that (WIS-155) obtained for an Oneota component at the site. In 1965 J. Mett Shippe collected charcoal samples from a cultural deposit associated with Oneota ceramics that provided this and one other date (WIS-151) (Bender et al. 1967:534; Henning 1970:145, 153) (Table 1). All but the first of these above-mentioned dates confirm a late prehistoric age for the Leary site; however, they do not discriminate between Central Plains and Oneota tradition occupations. Finally, an AMS date has recently been obtained on residue encrusted on the surface of an Oneota sherd originally excavated from a pit in 1935 (UCR 3945; Table 1). Due to the small size of the datable sample a broad age range was calculated. Like the Shippee dates the calibrated age of this sample places Oneota occupation of Leary in the Late Prehistoric period but does not distinguish it temporally from the lower 


\begin{tabular}{|c|c|c|c|c|c|c|c|c|}
\hline 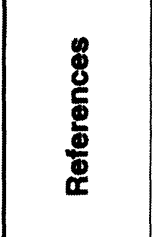 & 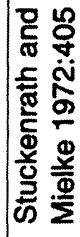 & 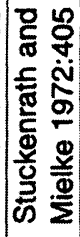 & 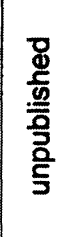 & 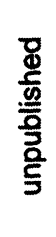 & 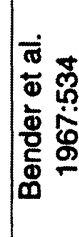 & 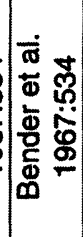 & 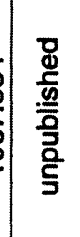 & \\
\hline 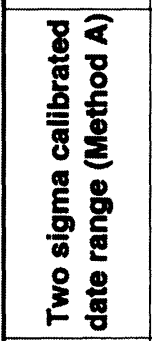 & 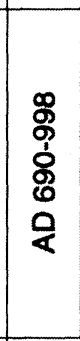 & 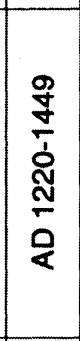 & 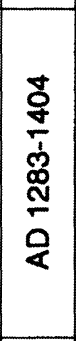 & 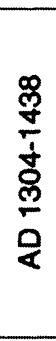 & $\frac{\frac{n}{7}}{\frac{8}{\delta}}$ & $\begin{array}{l}\frac{\mathscr{0}}{0} \\
\frac{9}{\dot{j}} \\
\frac{5}{5} \\
\frac{0}{<}\end{array}$ & $\frac{\hat{\sigma}}{\frac{N}{\infty}}$ & \\
\hline 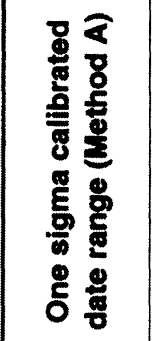 & 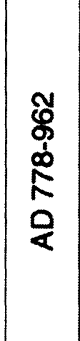 & 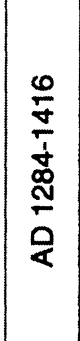 & 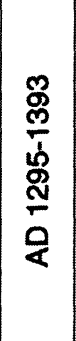 & 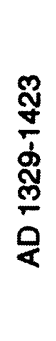 & 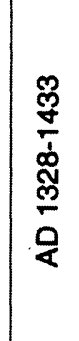 & 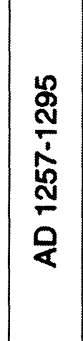 & $\frac{\mathscr{Y}}{\frac{Y}{+}}$ & 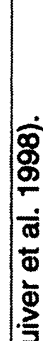 \\
\hline 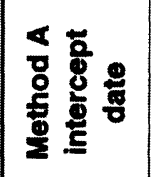 & $\widehat{\mathscr{\infty}}$ & 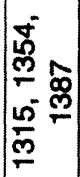 & 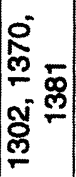 & $\stackrel{g}{\ddagger}$ & $\underset{+}{\stackrel{g}{+}}$ & 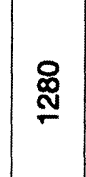 & 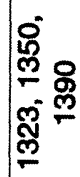 & 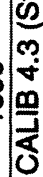 \\
\hline 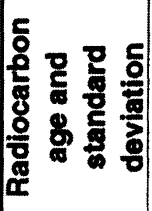 & $\begin{array}{l}8 \\
0 \\
\frac{1}{ \pm} \\
0 \\
\frac{1}{=}\end{array}$ & $\begin{array}{l}8 \\
\frac{1}{1} \\
\dot{1} \\
\stackrel{0}{0}\end{array}$ & $\begin{array}{l}\frac{9}{1} \\
\frac{1}{+} \\
\frac{8}{6}\end{array}$ & 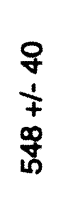 & 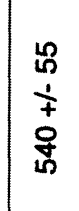 & 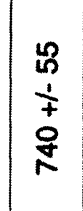 & $\begin{array}{l}\text { 음 } \\
\frac{1}{+} \\
0 \\
\frac{0}{6}\end{array}$ & 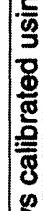 \\
\hline$\stackrel{\circ}{\stackrel{0}{\sigma}}$ & $\S$ & $\frac{\mathbb{z}}{\mathbf{z}}$ & 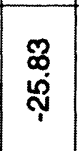 & 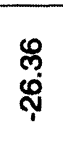 & $\frac{\widehat{\Sigma}}{z}$ & $\leqslant$ & 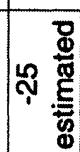 & 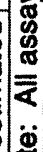 \\
\hline 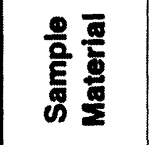 & $\begin{array}{l}\bar{\delta} \\
\frac{\delta}{\pi} \\
\frac{\pi}{0}\end{array}$ & $\begin{array}{l}\bar{\sigma} \\
\frac{0}{\pi} \\
\frac{\pi}{0}\end{array}$ & 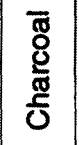 & $\begin{array}{l}\overline{\frac{0}{0}} \\
\frac{0}{\pi} \\
\frac{\pi}{0}\end{array}$ & 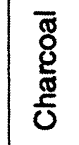 & $\begin{array}{l}\overline{8} \\
\frac{0}{\pi} \\
\frac{5}{0}\end{array}$ & 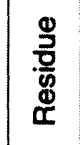 & z \\
\hline ฮ ํํㄹㄹㄹ & $\frac{\infty}{\varphi}$ & $\frac{\hat{\phi}}{\frac{1}{\omega}}$ & $\begin{array}{l}\bar{\delta} \\
\text { Nু } \\
\text { S্口 }\end{array}$ & 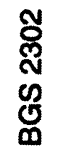 & 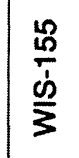 & $\frac{\overline{5}}{\frac{5}{3}}$ & 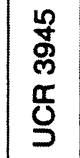 & \\
\hline 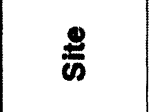 & 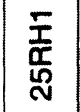 & 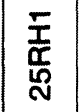 & $\begin{array}{l}\overline{\mathbf{I}} \\
\text { 営 } \\
\text { }\end{array}$ & 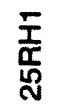 & 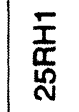 & 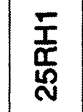 & $\begin{array}{l}\overline{\mathbf{I}} \\
\text { 营 } \\
\text { N }\end{array}$ & \\
\hline
\end{tabular}


occupation, which includes Nebraska phase materials. Statistical comparison of the means of the six late prehistoric dates from Leary shows no meaningful variation (Brad Logan, personal communication 2001). These data, in combination with the stratigraphic findings discussed above, may support contemporaneous occupation by Nebraska phase and Oneota tradition peoples in the lowest excavated levels of the Leary site and in the region during the stratigraphically later period of occupation of Leary. On the other hand, these data may simply be too imprecise to reveal temporally close but distinct occupations. The same can be said for the utility of radiocarbon dating for distinguishing between multiple Oneota components at the Leary site.

Other issues that have been raised about Leary over the years are the potential role of this site as an Oneota exchange center and its relationship to other Western Oneota manifestations in the region. Henning (1995:83, 1998:394) hypothesized that the Leary site served as a regional exchange center for the Western Oneota. Its location along the Nemaha and Missouri rivers placed it along major transportation routes in the region (Figure 2). Movement of goods and people between Leary and Oneota sites to the south and north (for instance, to and from the Utz site in central Missouri and the Dixon and neighboring sites in northwestern Iowa) would have been possible using the Missouri River as an avenue for travel. The Nemaha River may also have marked a route to the west. Preliminary macroscopic identification of lithic materials, curated as part of the 1935 and 1965 Leary site assemblages, reveals that at least five percent are non-local. They include Burlington cherts, Niobrara jasper (Smoky Hill silicified chalk; Smoky Hill, Republican River, or Graham County jasper; or Niobrarite), Ogallala orthoquartzite, Flattop chalcedony, cherts of the Hartville Uplift region, and Alibates agatized dolomite.

More detailed raw material studies of the Leary and other Oneota assemblages may shed light on exchange between peoples and the movement of populations between regions and specific locations. Fishel (1999) used this approach to interpret the movement of Oneota peoples between the Dixon site in northwestern Iowa and the central Plains via the Leary site for large-scale bison hunts. If
Leary did serve as a jump-off point for western hunts, it is likely that cultural, possibly kin, ties existed between the occupants of these two sites. It has also been hypothesized that the Leary site was a point of origin for Oneota migrants that moved even further to the west and into the heart of the central Plains (Logan 1995, 1998; Ritterbush 2000). The archaeological remains of these migrants are assigned to the White Rock phase and are found in north-central Kansas and southern $\mathrm{Ne}$ braska (Figure 2). Although lithic materials from that region are found in the Leary assemblage, interpreting the relationship between the occupants of the Leary site and the western plains remains elusive.

These hypotheses regarding exchange and the movement and mobility patterns of the Western Oneota emphasize the importance of the Leary site in Oneota prehistory. The presence of Oneota remains in the central Plains is not surprising given the overall wide distribution of Oneota sites in the upper Midwest and surrounding regions (Figure 2). The Leary site can be viewed as one of a number of archaeological sources that may yet yield significant information regarding a broad understanding of Oneota "culture" and expansion.

Likewise, the Leary site holds great promise for understanding the cultural dynamics of the central Plains during the Late Prehistoric period. The stratification of Nebraska phase, Oneota tradition, and Steed-Kisker phase deposits at the Leary site, combined with overlapping radiocarbon dates suggest concurrent or closely sequential occupations by peoples of different cultural traditions. Understanding the association of archaeological remains at this site is necessary for interpreting possible social relations between these prehistoric groups.

\section{ACKNOWLEDGMENTS}

This article is a modified version of a paper presented at the $58^{\text {th }}$ Annual Meeting of the Plains Anthropological Society. I extend my appreciation to Brad Logan for inviting me to participate in the symposium entitled "Prehistory of the Lower Missouri Valley" organized in honor of Alfred E. Johnson. Brad also deserves my gratitude for his patience and insightful comments regarding reanalysis of the Leary site and for making materials from the Scott site (14LV1082) available to me for comparative purposes. Ongoing research into Leary has been supported by the National Science Foundation under Grant No. EPS-9874732 and matching support from the State of Kansas. Recent radiocarbon and AMS dates were funded by a University 
Small Research Grant from Kansas State University. Jeannette Blackmar, then of the Archaeology Division of the Nebraska State Historical Society, graciously provided assistance with obtaining information about and access to research materials at that institution, as did her successor Rene Botts. Likewise, Rob Bozell directed me to useful information about the NSHS collections. Karen O'Brien and John Cordell of the University of Michigan Museum of Anthropology and the Office of the State Archaeologist at the University of Iowa, respectively, kindly and efficiently provided information about and arranged loans of Leary materials from those institutions. Beth Wilkins has provided useful information about the collections made in 1939 and 1960. Figures 3-7 are courtesy of the Nebraska State Historical Society. Matt Padilla assisted with the computer graphics for Figures 1 and 7, and Joe Loretta constructed Figure 2. While at Kansas State University Jessica L. Middleton and Tobin W. Roop provided invaluable aid with the ceramic and lithic data collection for the Leary site assemblages. My thanks to them for their hard work and dedication to these often tedious tasks. This manuscript has benefited greatly from comments on earlier drafts by and various conversations with Rich Fishel, Bill Green, Dale Henning, Eric Hollinger, and John Ludwickson. I offer my sincere thanks to everyone who has helped in so many ways with this on-going research.

\section{REFERENCES}

\section{Anonymous}

2000 Report of Human Remains in Compliance with the Native American Graves Protection and Repatriation Act, Peabody Museum of Archaeology and Ethnology, Harvard University. Report on file, Bureau of Indian Affairs file, Repatriation Department, Peabody Museum of Archaeology and Ethnology, Cambridge, Massachusetts.

Bass, W. M.

19611960 Excavations at the Leary Site, 25RH1, Richardson County, Nebraska. Plains Anthropologist 6(13):201-204.

Bender, M. M., R. A. Bryson, and D. A. Baerreis

1967 University of Wisconsin Radiocarbon Dates III. Radiocarbon 9:530-544.

Blackman, E. E.

ca. 1926 The Ancient Indian Ruin in Richardson County, Nebraska. Manuscript on file, Nebraska State Historical Society, Archaeology Division, Lincoln.

Boszhardt, R. F.

1998 Oneota Horizons: A La Crosse Perspective. The Wisconsin Archaeologist 79(2):196-226.

Bozell, J. R. and J.Ludwickson

1999 Archeology of the Patterson Site: Native American Life in the Lower Platte Valley. Nebraska State Historical Society, Highway Archeology Program, Lincoln. Submitted to the Nebraska Department of Roads.

Bozell, J. R., J. Ludwickson, A. Koch, and M. J. Adair

1999 Perspectives on the Late Prehistory of the South Bend Locality. In Archeology of the Patterson Site: Native American Life in the Lower Platte Valley, by J. R. Bozell and J. Ludwickson, pp. 101-141. Nebraska State Historical Society, Highway Archeology Program, Lincoln. Submitted to the Nebraska Department of Roads.
Calabrese, F. A.

1969 Doniphan Phase Origins: An Hypothesis Resulting from Archeological Investigations in the Smithville Reservoir Area, Missouri: 1968. University of Missouri Archaeological Research, Department of Anthropology, Columbia. Submitted to the National Park Service, Midwest Region, U.S. Department of the Interior.

Corbyn, R. C.

1975 National Register of Historic Places Inventory Nomination Form, Leary Site (25RH1). Form on file, Nebraska State Historical Society, Lincoln.

Fishel, R. L. (editor)

1999 Bison Hunters of the Western Prairies: Archaeological Investigations at the Dixon Site (13WD8), Woodbury County, Iowa. Office of the State Archaeologist Report 21. University of Iowa, Iowa City

Fowke, G.

1922 Explorations along the Missouri River Bluffs in Kansas and Nebraska. Bureau of American Ethnology Bulletin 76:151-160. Smithsonian Institution, Washington D.C.

Frantz, W.

1966 Excavations of the Nebraska State Historical Society at the Leary Site (25RH1), 1965. Plains Anthropologist 11(32): 163 .

Garrett, J. and W. Frantz

19651965 Field Notes 25RH1. Notes on file at the Nebraska State Historical Society, Archeology Division, Lincoln.

Garst, C. D.

2002 Relative Dating of the Oneota Occupations at the Leary Site (25RH1): A Study of the 1968 Field Season's Ceramic Artifacts. Unpublished Master's thesis, Department of Anthropology, University of Kansas, Lawrence.

Gunnerson, J. H.

1952 Some Nebraska Culture Pottery Types. Plains Anthropological Conference Newsletter 5(3):39-49.

Henning, D. R.

1961 Oneota Ceramics in Iowa. Journal of the Iowa Archeological Society 11(2).

1970 Development and Interrelationships of Oneota Culture in the Lower Missouri River Valley. The Missouri Archaeologist 32.

1995 Oneota Evolution and Interactions: A Perspective from the Wever Terrace, Southeast Iowa. In Oneota Archaeology: Past, Present, and Future, edited by W. Green, pp. 65-88. Office of the State Archaeologist Report 20. Office of the State Archaeologist, University of Iowa, Iowa City.

1998 The Oneota Tradition. In Archaeology on the Great Plains, edited by W. R.Wood, pp. 345-414. University Press of Kansas, Lawrence.

Hill, A. T. and P. Cooper

1937 The Archeological Campaign of 1937. Nebraska History Magazine 18(4):243-359.

Hill, A. T. and W. R. Wedel

1936 Excavations at the Leary Indian Village and Burial Site, Richardson County, Nebraska. Nebraska History Magazine 17(1):1-73.

Hollinger, R. E.

1993 Investigating Oneota Residence through Domestic 
Architecture. Unpublished Master's thesis, Department of Anthropology, University of Missouri, Columbia.

Ives, J. C.

1955 Glenwood Ceramics. Journal of the Iowa Archaeological Society 4(3-4):2-32.

Johnson, C. G.

1993 The Leary Site: An Archaeological Investigation of 25RH1. Report prepared for the U.S. Department of Interior, Bureau of Indian Affairs, Anadarko Area Office by the Archaeological Research Laboratory, Department of Anthropology, Wichita State University.

Keyes, C. R.

1938 Review of Excavations at the Leary Indian Village and Burial Site, Richardson County, Nebraska, by A.T. Hill and W. R. Wedel. American Antiquity 3:290-293.

Logan, B.

1995 Phasing in White Rock: Archaeological Investigation of the White Rock and Warne Sites, Lovewell Reservoir, Jewell County, Kansas, 1994-1995. Project Report Series 90.University of Kansas, Museum of Anthropology, Lawrence.

1998 Oneota Far West: The White Rock Phase. The Wisconsin Archeologist 79(2):248-267.

McManamon, F. P.

1997 Notice of Inventory Completion for Native American Human Remains and Associated Funerary Objects From Nebraska in the Possession of the Nebraska State Historical Society, Lincoln, NE. Federal Register 62(181):49026-49027.

Middleton, J. L.

2001 A Nebraska Phase Occupation at the Leary Site. Manuscript on file with the author.

Moulton, G. E. (editor)

1986 The Journals of the Lewis \& Clark Expedition, vol. 2. University of Nebraska Press, Lincoln.

O'Brien, M. J. and W. R. Wood

1998 The Prehistory of Missouri. University of Missouri Press, Columbia.

Pepperl, R. E.

2000 Survey and Testing Investigations for a National Register District Nomination, Vol 1: Reassessment of the
Ashland Site (25CC1) Complex, Cass and Saunders Counties, Nebraska. Nebraska State Historical Society Archeological Survey Report. Nebraska State Historical Society, Lincoln.

Raish, C. B.

1979 King Hill (23BN1), Fanning (14DP1) and Leary (25RH1): A Study of Oneota Ceramic Variability. Unpublished Master's thesis, University of Nebraska, Lincoln.

Ritterbush, L. W.

2000 Analyzing Western Oneota Migration. Current Archaeology in Kansas 1:13-17.

Steinacher, T. L. and G. F. Carlson

1998 The Central Plains Tradition. In Archaeology on the Great Plains, edited by W. R. Wood, pp. 235-268. University Press of Kansas, Lawrence.

Sterns, F. H.

ca. 1915 Original unpublished field notes. Accession file 156, pp. 19-21. On file at the Peabody Museum, Harvard University, Cambridge.

Strong, W. D.

1935 An Introduction to Nebraska Archaeology. Smithsonian Miscellaneous Collections 93(10). Smithsonian Institution, Washington D.C.

Stuckenrath, R. and J. E. Mielke

1972 Smithsonian Institution Radiocarbon Measurements VII. Radiocarbon 14(2):401-412.

Stuiver, M., P. J. Reimer, E. Bard, J. W. Beck, G. S. Burr, K. A. Hughen, B. Kromer, F. G. McCormac, J. v. d. Plicht and M. Spurk

1998 INTCAL 98 Radiocarbon Age Calibration 24,000-0 cal BP. Radiocarbon 40:1041-1083.

Wedel, W. R.

1943 Archeological Investigations in Platte and Clay Counties, Missouri. United States National Museum Bulletin 183. Government Printing Office, Washington D. C.

Zimmerman, M. E.

1918 Ground-house Indians and Stone-cist Grave Builders of Kansas and Nebraska. Collections of the Kansas State Historical Society 14:471-487. 